\title{
SINKRONISASI PERATURAN PERUNDANG-UNDANGAN TENTANG KEBIJAKAN BEBAS VISA KUNJUNGAN
}

\author{
Erikson Sihotang \\ Fakultas Hukum Universitas Mahendradatta, Jalan Ken Arok Nomor 12 \\ Denpasar \\ (sihotang_soupiterta@yahoo.com)
}

\begin{abstract}
Abstrak, Untuk menjamin kemanfaatan dan melindungi berbagai kepentingan nasional serta dalam rangka menegakkan kedaulatan negara di bidang keimigrasian maka perlu ditetapkan prinsip, tata pengawasan, tata pelayanan atas masuk dan keluarnya orang ke dan dari wilayah Indonesia. Pengaturan tentang Bebas Visa Kunjungan dalam perundang-undangan Indonesia ada ketidaksinkronan satu sama lainnya terhadap pemberlakuan bebas visa kunjungan yang berasaskan asas timbal balik (resiprositas) dan asas manfaat. UndangUndang Keimigrasian menentukan pemberian bebas visa harus memperhatikan asas timbal balik dan asas manfaat, sementara Peraturan Presiden tentang Bebas Visa Kunjungan menentukan tujuan pemberian bebas visa untuk negara tertentu adalah dalam rangka kunjungan wisata. Dengan demikian maka baik asas resiprositas maupun asas manfaat yang menjadi dasar pertimbangan pemberian bebas visa kunjungan belum terpenuhi dalam kebijakan Peraturan Presiden tentang Bebas Visa Kunjungan.

Kata Kunci : sinkronisasi, peraturan perundang-undangan, dan bebas visa kunjungan.
\end{abstract}

Abstract, In order to guarantee the benefits and protect various national interests as well as in the framework of upholding the state's sovereignty in the immigration sector, it is necessary to stipulate principles, supervision systems, service procedures for the entry and exit of people into and from the territory of Indonesia. The regulation on Visit Visa Free in Indonesian legislation is inconsistent with each other with the application of free visit visas on the basis of reciprocity and the principle of benefit. The Immigration Law stipulates that the granting of visa exemptions must pay attention to the principle of reciprocity and the principle of benefit, while the Presidential Regulation on Visit Visa Free stipulates that the purpose of granting visa exemptions for certain countries is in the framework of tourist visits. Thus, neither the reciprocity principle nor the benefit principle which is the basis for the consideration of granting visit visa exemptions has not been fulfilled in the policy of the Presidential Regulation on Visit Visa Free.

Keywords: synchronization, statutory regulations, and visa-free visits.

I. Pendahuluan

\section{A. Latar Belakang}

Negara berdaulat berarti

Negara mempunyai kekuasaan tertinggi. Sehingga tidak mengakui suatu kekuasaan yang lebih tinggi dari kekuasaannya tersebut. Negara dikatakan 
berdaulat karena kedaulatan merupakan suatu sifat atau ciri hakiki Negara. Bila dikatakan bahwa Negara itu berdaulat, dimaksudkan bahwa Negara itu mempunyai kekuasaan tertinggi. Ruang berlaku kekuasaan tertinggi ini dibatasi oleh batas wilayah Negara itu, artinya suatu Negara hanya memiliki kekuasaan tertinggi di dalam batas wilayahnya. Suatu negara yang merdeka, maka ia mempunyai hak-haknya, seperti yurisdiksi teritorial dan mempertahankan negaranya. Di samping hak terdapat kewajibannya yang mengikat atau berhubungan dengan negara lain, seperti tidak mengambil jalan kekerasan, traktat dengan iktikad baik, dan tidak intervensi. Prinsip menghormati kedaulatan teritorial suatu negara salah satu contoh hak sekaligus kewajiban.

$$
\text { Dalam hukum }
$$

internasional dikenal suatu prinsip yang mengatakan "par in parem non hebat yurisdcsionem", yang artinya bahwa setiap Negara mempunyai kedudukan yang sama dan sejajar, tidak ada satu negara yang melaksanakan yurisdiksinya terhadap negaralain tanpa dengan persetujuan negara lain tersebut, (http://karimjogja.blogspot.co.id/ Arti Kedaulatan Negara Dalam Hukum Internasional, diunduh, 2 Januari 2017). Doctrine of the equality of states oleh Christian Wolf: Pada dasarnya semua bangsa mempunyai kedudukan yang sama satu sama lain. Karena bangsa-bangsa dianggap sebagai pribadi manusia bebas yang hidup dalam suatu keadaan alami, oleh karena itu, karena pada dasarnya semua manusia memiliki kedudukan yang sama, maka semua bangsa pun pada dasarnya berkedudukan sama satu sama lain"( http://karimjogja.blogspot.co.id/ Arti Kedaulatan Negara Dalam Hukum Internasional, diunduh, 2 Januari 2017).

Sehubungan dengan kemerdekaan dan kedaulatan negara ini, Konvensi Montevideo pada tahun 1933 menyatakan 
bahwa suatu negara harus memiliki 4 (empat) unsur, yaitu:

1. Rakyat yang permanen

2. Wilayah atau daerah yang tetap

3. Pemerintah

4. Kemampuan

untuk mengadakan hubungan dengan negara lain

Kedaulatan suatu negara mencakup keempat unsur di atas yang berarti juga kekuasaan absolut suatu negara atas unsurunsur tersebut.

Negara Indonesia adalah negara yang merdeka dan berdaulat berdasarkan proklamasi kemerdekaan Indonesia tanggal 17 Agustus 1945 yang berarti bebas dari penjajahan dan intervensi negara lain, bebas menentukan dan mengatur diri sendiri dan bebas berhubungan dengan negara lain dalam tatanan hubungan internasional. Pasal 1 ayat (2) Undang-Undang Dasar Negara Indonesia menyatakan bahwa kedaulatan adalah di tangan rakyat dan dilaksanakan menurut Undang-Undang Dasar. Kedaulatan adalah kekuasaan tertinggi dari suatu negara merdeka yang tidak bisa diintervensi oleh negara lain. Kedaulatan bersifat absolut yang mengikat setiap wilayah dan penduduk yang ada di dalamnya. Kedaulatan adalah sifat hakiki dari suat negara yang bebas merdeka, (Mochtar Kusumaatmadja dan Etty R. Agoes, 2010:16). Menurut sejarah, asal kata kedaulatan yang dalam bahasa Inggris dikenal dengan istilah souvereignity berasal dari bahasa Latin superanus yang berarti yang teratas. Negara yang berdaulat berarti negara yang memiliki kekuasaan tertinggi untuk menjalankan negaranya tanpa ada campur tangan dari negara lain.

Hubungan internasional terjalin karena adanya saling ketergantungan antar negara untuk memenuhi kebutuhan negara tersebut. Tidak ada satu negara pun yang bisa hidup sendiri tanda adanya bantuan atau kerja sama dengan negara lain. Hubungan Internasional 
mengadung arti adanya suatu kerja sama yang bersifat internasional (antar negara). Kerja sama yang dibentuk tersebut harus tunduk kepada kaidah-kaidah Hukum Internasional.

Salah satu bentuk kerjasama internasional adalah kerjasama dalam hal lalu lintas orang maupun barang/jasa antar negara. Pada karya tulis ini, Penulis hanya membahas lalu lintas orang antar negara terutama lalu lintas orang asing yang akan masuk atau keluar dari wilayah negara Indonesia. Kedaulatan negara di perbatasan dan di setiap pintu masuk ke wilayah Indonesia harus ditegakkan. Penegakan kedaulatan terhadap teritorial wilayah negara dilaksanakan oleh Tentara Nasional Indonesia sedangkan penegakan kedaulatan negara terhadap setiap orang yang akan masuk atau keluar wilayah negara Indonesia dilaksanakan oleh Direktorat Jenderal Imigrasi Kementerian Hukum dan Hak
Asasi Manusia Republik Indonesia.

Seiring dengan perkembangan jaman terutama di bidang hukum internasional yang mengatur tentang wilayah negara serta perkembangan pergaulan internasional maka pemerintah Indonesia memandang perlu menyusun suatu Undang-Undang Keimigrasian yang terpadu mencakup seluruh permasalahan Keimigrasian yang ada sesuai dengan perkembangan jaman. Pada tahun 1992 terbentuklah Undang-Undang yang mengatur tentang keimigrasian yaitu Undang-Undang Nomor 9 Tahun 1992 yang kemudian diganti dengan Undang-Undang Nomor 6 Tahun 2011 sebagai UndangUndang yang terbaru tentang Keimigrasian. Pasal 1 Angka (1) Undang-Undang Nomor 6 Tahun 2011 menyebutkan: "Keimigrasian adalah hal ihwal lalu lintas orang yang masuk atau keluar Wilayah Indonesia serta pengawasannya dalam rangka menjaga tegaknya kedaulatan negara." 
Untuk menjamin kemanfaatan dan melindungi berbagai kepentingan nasional serta dalam rangka menegakkan kedaulatan negara di bidang keimigrasian maka perlu ditetapkan prinsip, tata pengawasan, tata pelayanan atas masuk dan keluarnya orang ke dan dari wilayah Indonesia sesuai dengan nilai-nilai dan tujuan nasional Negara Republik Indonesia yang berdasarkan Pancasila dan Undang-Undang Dasar 1945.

Terhadap orang asing, pemberian ijin keimigrasian dan pengawasannya dilaksanakan berdasarkan prinsip yang bersifat selektif (selective policy). Berdasarkan prinsip ini maka hanya orang asing yang dapat memberikan manfaat bagi kesejahteraan rakyat, bangsa dan Negara Republik Indonesia serta tidak membahayakan keamanan dan ketertiban umum serta tidak bermusuhan baik terhadap rakyat maupun Negara Republik Indonesia yang boleh masuk atau keluar wilayah Indonesia.
Setiap orang asing yang akan masuk ke wilayah Indonesia harus memiliki visa atau izin masuk ke wilayah Indonesia kecuali bagi mereka yang negaranya dibebaskan dari kewajiban memiliki visa. Pengertian Visa diatur dalam Undang-Undang Nomor 6 Tahun 2011 Pasal 1 Angka (18) yang berbunyi: "Visa Republik Indonesia yang selanjutnya disebut Visa adalah keterangan tertulis yang diberikan oleh pejabat yang berwenang di Perwakilan Republik Indonesia atau di tempat lain yang ditetapkan oleh Pemerintah Republik Indonesia yang memuat persetujuan bagi Orang Asing untuk melakukan perjalanan ke Wilayah Indonesia dan menjadi dasar untuk pemberian Izin Tinggal."

Dasar hukum pemberlakuan pemberian Visa Kunjungan Saat Kedatangan adalah Keputusan Menteri Kehakiman dan Hak Asasi Manusia Republik Indonesia Nomor M-04.IZ.01.10 Tahun 
2003 tentang Visa Kunjungan

Saat Kedatangan yang

mengalami perubahan sampai

dengan perubahan yang

kesebelas pada tahun 2009 agar

sesuai dengan pergaulan

internasional dan perkembangan

hukum internasional. Namun

pada akhirnya, Peraturan Menteri

tersebut diganti dengan peraturan

menteri yang terbaru yaitu

Peraturan Menteri Hukum dan

Hak Asasi Manusia Republik

Indonesia Nomor M.HH-01-

GR.01.06 Tahun 2010 tentang

Visa Kunjungan Saat

Kedatangan.

Pengertian Visa

Kunjungan Saat Kedatangan

dijelaskan melalui pasal 1 butir 1

Peraturan Menteri Hukum dan

Hak Asasi Manusia Republik

Indonesia Nomor M.HH-01-

GR.01.06 Tahun 2010 tentang

Visa Kunjungan Saat Kedatangan

yang berbunyi "Visa Kunjungan

Saat Kedatangan yang

selanjutnya disingkat dengan

VKSK adalah Visa Kunjungan

atas kuasa Direktur Jenderal

Imigrasi yang diberikan kepada
Warga Negara Asing pada saat tiba di wilayah Indonesia".

Pada tanggal 9 Juni 2015 Presiden mengeluarkan Peraturan Presiden Nomor 69 Tahun 2015 tentang Bebas Visa Kunjungan yang isinya memuat pemberian kebijakan bebas visa kunjungan kepada 45 negara dengan rincian 15 negara penerima bebas visa terdahulu yang sebelumnya diatur dalam Keputusan Presiden Nomor 18 Tahun 2003 tentang Bebas Visa Kunjungan Singkat sebagaimana telah beberapa kali diubah terakhir dengan Peraturan Presiden Nomor 43 Tahun 2011 tentang Perubahan Ketiga atas Keputusan Presiden Nomor 18 Tahun 2003 ditambah dengan 30 negara baru dengan alasan utama untuk meningkatkan angka kunjungan wisata dari orang asing yang akan masuk ke Indonesia. Dengan adanya peningkatan angka kunjungan wisatawan mancanegara diharapkan akan meningkatkan pendapatan devisa negara dari sektor pariwisata. Peraturan presiden ini dimaksudkan untuk 
mempermudah lalu lintas orang asing yang akan datang ke Indonesia dalam rangka wisata.

\section{B. Rumusan Masalah}

Peraturan Presiden

Nomor 69 Tahun 2015 tentang Bebas Visa Kunjungan menimbulkan permasalahan hukum baru karena ada dualisme penerapan kebijakan yang sama terhadap beberapa negara dengan tujuan yang sama. Dualisme tersebut adalah untuk 15 negara awal diberlakukan asas resiprositas sementara untuk 30 negara baru tidak berlaku asas resiprositas sementara kebijakan yang diberikan sama yaitu diberikan bebas visa kunjungan dan masalah lain yang timbul akibat penerapan pemberian bebas visa kunjungan ini yaitu peraturan pelaksana yang kurang tegas dan memberikan ruang kepada orang asing untuk menyalahgunakan kebijakan ini. Yang menjadi permasalahan dalam tulisan ini adalah apakah kebijakan pemberian bebas visa kunjungan berdasarkan Peraturan Presiden Nomor 69 Tahun 2015 tentang Bebas Visa Kunjungan bertentangan dengan Undang Undang Nomor 6 Tahun 2011 Tentang Keimigrasian dalam hal asas pemberlakuan kebijakan?

\section{Tujuan dan Kegunaan}

Tujuan dari penelitian ini adalah untuk mengetahui, memahami, menelaah, dan menganalisis kebijakan pemberian bebas visa kunjungan berdasarkan Peraturan Presiden Nomor 69 Tahun 2015 tentang Bebas Visa Kunjungan bertentangan dengan Undang Undang Nomor 6 Tahun 2011 Tentang Keimigrasian dalam hal asas pemberlakuan kebijakan.

Adapun kegunaan dari penelitian ini adalah:(a) bagi pengembangan ilmu pengetahuan, penelitian ini diharapkan dapat memberikan manfaat bagi pengembangan ilmu pengetahuan hukum, terutama mengenai hal-hal yang berkaitan dengan keimigrasian. dan (b) bagi praktik, penelitian ini diharapkan akan memberikan manfaat agar para pengambil 
kebijakan di lapangan dapat bekerja dengan benar.

\section{Studi Pustaka}

Perbatasan merupakan salah satu manifestasi penting dalam kedaulatan teritorial negara. Perbatasan dapat diakui dengan tegas dalam traktak atau. umum diakui tanpa pernyataan tegas. Perbatasan bukan hanya garis maginer di atas permukaan bumi, melainkan suatu garis yang memisahkan satu daerah dengan daerah lainnya. Perbatasan bukan semata-mata sebuah garis tetapi sebuah garis dalam daerah perbatasan. Kejelasan batas wilayah suatu negara dibutuhkan dalam rangka menjaga kedaulatan, pertahanan, keamanan, dan keutuhan teritorial suatu Negara (J.G. Starke, 1989:95-96).

\section{Berkaitan dengan}

perbatasan, di setiap perbatasan antar negara terdapat Tempat Pemeriksaan Imigrasi. Setiap orang yang melakukan perjalanan melintasi batas suatu negara baik itu masuk ataupun keluar dari wilayah Indonesia harus melalui pemeriksaan oleh Pejabat Imigrasi di Tempat Pemeriksaan Imigrasi.

Kedaulatan adalah kekuasaan tertinggi yang dimiliki oleh suatu negara untuk secara bebas melakukan berbagai kegiatan/sesuai kepentingannya asal saja kegiatan tersebut tidak bertentangan dengan hukum internasional. Sesuai konsep hukum internasional, kedaulatan memiliki tiga aspek utama yaitu: ekstern, intern dan territorial, (Boer Mauna, 2001 : 24).

Dalam melindungi kedaulatan Negara, Direktorat Jenderal Imigrasi selaku pintu gerbang Negara menerapkan politik keimigrasian berupa selective policy (politik saringan). Indonesia merubah kebijaksanaan opendeur politiek menjadi selective policy pada tahun 1950 setelah terbentuknya Negara Kesatuan Rl di bawah Undang-Undang Dasar Sementara (UUDS), (Ramadhan Kh, abrar Yuara, 2005:53). Selective policy adalah kebijaksanaan imigrasi yang 
bersifat selektif atau saringan dan didasarkan pada perlindungan kepentingan nasional dan lebih menekankan prinsip pemberian perlindungan yang lebih besar kepada warga Negara Indonesia.

Sebagaimana dijelaskan sebelumnya bahwa Keimigrasian adalah hal ihwal lalu lintas orang yang masuk atau keluar Wilayah Indonesia serta pengawasannya dalam rangka menjaga tegaknya kedaulatan negara. Dalam rangka menjaga tegaknya kedaulatan negara diperlukan suatu hukum yang mengatur hal tersebut.

Konsep hukum dan negara berdasarkan atas hukum adalah adanya jaminan penegakan hukum dan tercapainya tujuan hukurn. Dalam penegakan hukum ada tiga unsur yang selalu harus mendapat perhatian, yaitu keadilan, kemanfaatan atau hasil guna (doelmatigheid), dan kepastian hukum, Sudikno Metokusumo dan A. Pitlo, 1993 : 1). Tujuan pokok dari hukum adalah ketertiban. Kebutuhan atau ketertiban ini, syarat pokok untuk suatu masyarakat yang teratur. Tujuan lain dan hukum adalah tercapaiya keadilan. Untuk mencapai ketertiban dibutuhkan kepastian hukum dalam pergaulan antar manusia dalam masyarakat, (Muchtar Kusumaatmadja, tanpa tahun ; 1). Hukum harus dilaksanakan dan ditegakkan. Setiap orang mengharapkan ditetapkannya hukum dalam hal terjadinya peristiwa konkrit. Itulah yang diinginkan oleh kepastian hukum. Masyarakat inengharapkan adanya kepastian, karena dengan adanya kepastian hukum masyarakat akan lebih tertib. Hukum bertugas menciptakan kepastian hukum karena bertujuan untuk ketertiban masyarakat. Penegakan hukum harus memberi manfaat pada masyarakat, di samping bertujuan menciptakan keadilan.

Teori perundangundangan (gezetgebungstheorie) pada dasarnya merupakan bagian dari ilmu pengetahuan perundang-undangan (gezetgebungswissemschaft) yang 
berupaya mencari kejelasan

makna atau pengertian hukum dan peraturan perundangundangan secara kognitif, (Soeprapto dan Maria Farida Indrati, $1998: 7-8)$.

\section{Salah seorang}

intelektual mashab hukum murni yang pemikirannya tentang Grundnorm dan hierarkhi norma hukum berpengaruh besar terhadap konstruksi hierarkhi perundang-undangan di berbagai Negara yakni Hans Kelsen, mengkategorikan hukum sebagai norma yang dinamik (Normdynamics). Menurut konsep ini hukum adalah sesuatu yang dibuat melalui suatu prosedur tertentu dan segala sesuatu yang dibuat menurut cara ini adalah hukum. Dalam kaitannya dengan konstitusi, hukum dikonsepsikan sebagai sesuatu yang terjadi menurut cara yang ditentukan konstitusi bagi pembentukan hukum.

Lebih jauh Hans Kelsen mengemukakan tentang karakter khas dan dinamis dari hukum, yaitu "Hukum mengatur pembentukannya sendiri karena suatu norma hukum menentukan cara untuk membuat suatu norma hukum lainnya, dan juga sampai derajat tertentu menentukan isi norma lainnya tersebut. Hubungan antara norma yang mengatur pembentukan norma lain dengan norma lainnya digambarkan sebagai hubungan antara "Superordinasi" dan "Subordinasi". Kesatuan normanorma ini ditunjukkan oleh fakta bahwa pembentukan norma yang lebih rendah ditentukan oleh norma lain yang lebih tinggi, dan bahwa regresus ini diakhiri oleh suatu norma dasar, oleh karena menjadi dasar tertinggi dari validitas keseluruhan tata hukum, membentuk kesatuan tata hukum".

Selanjutnya Kelsen mengemukakan teorinya tentang tata urutan atau susunan hierarkhi dari tata hukum suatu negara yaitu dengan memformulasikan norma dasar, yakni konstitusi dalam arti material adalah urutan tertinggi didalam hukum nasional. Sebagaimana 
ditegaskan bahwa: "The legal order ... is therefore not a system of norms coordinated to each, standing, so to speak, side by same level, but hierarchy of different level norms", (Hans Kelsen, 1986 : 1). Masih

menurut Kelsen, kendati konstitusi merupakan puncak tertinggi dalam hierarkhi norma hukum, namun tidak tertutup kemungkinan terjadinya konflik atau penyimpangan peraturan dari konstitusi. Mengenai hal ini, Kelsen mengemukakan prinsip lex posterior derogat legi priori untuk mengatasi terjadinya konflik hukum tersebut.

Gagasan Kelsen mengenai berjenjangnya lapisan norma hukum dalam suatu hierarkhi, kelak dikemudian hari dikenal sebagai teori jenjang hierarkhi norma hukum (stufen theory). Sebagaimana yang diungkapkan oleh Bagir Manan, ajaran tata urutan pertingkatan perundang-undangan (stufenbau des recht) mengandung makna : Pertama, peraturan yang lebih rendah harus mempunyai sumber atau dasar pada peraturan yang lebih tinggi, Kedua, peraturan perundang-undangan untuk menjamin sebuah tertib hukum (legal order) dan Ketiga, peraturan perundang-undangan untuk menjamin tata urutan itu dalam suatu sistem yang tertib, (Bagir Manan, 2000).

\section{Undang-Undang}

Nomor 12 Tahun 2011 tentang Pembentukan Peraturan Perundang-undangan juga menganut asas lex superiori derogat lex inferiori, sebagaimana bunyi Pasal 7 ayat (5) : "Kekuatan hukum peraturan perundang-undangan adalah sesuai dengan hierarkhi sebagaimana dimaksud ayat (1)". Dalam penjelasannya dijabarkan bahwa : "yang dimaksud dengan hierarkhi adalah penjenjangan setiap jenis peraturan perundangundangan yang didasarkan pada asas bahwa peraturan perundangundangan yang lebih rendah tidak boleh bertentangan dengan peraturan perundang-undangan yang lebih tinggi." 


\begin{abstract}
Peraturan perundangundangan tentang keimigrasian selalu mengalami perubahan karena mengikuti perkembangan manusia yang terus berubah sehingga hukum yang mengatur tentang keimigrasian adalah suat hukum yang bersifat dinamis (bergerak) bukan hukum yang bersifat statis (diam). Hal ini sesuai dengan teori Hukum Murni yang disampaikan oleh Hans Kelsen di mana Teori Hukum Dinamis melihat obyek hukum pada proses ketika hukum itu diciptakan atau diterapkan, (Hans Kelsen, 2011 : 81).
\end{abstract}

\section{Metode Penelitian}

Penelitian ini adalah
penelitian normative dengan
mengkaji permasalahan yang
diangkat dari adanya kesenjangan
dalam norma / asas hukum yang
mengatur tentang keimigrasian
dikaitkan dengan peraturan
perundang-undangan yang
berlaku dan teori-teori yang ada
untuk kemudian dihubungkan
dengan kenyataan yang ada di
lapangan. Pendekatan masalah
menggunakan pendekatan

perundang-undangan (the statue approach). Pendekatan perundang-undangan adalah dengan menganalisa dan meneliti Peraturan Presiden Nomor 69 Tahun 2015 tentang Bebas Visa Kunjungan khususnya pada bagian latar belakang pemberian kebijakan dan asas yang mendasari kebijakan tersebut yang akan dibandingkan dengan kenyataan di lapangan tentang tata cara pemberian bebas visa kepada warga negara Indonesia oleh negara-negara yang sudah ditetapkan sebagai subyek bebas visa kunjungan ke Indonesia.

III. Hasil dan Pembahasan

A. Asas Timbal Balik Sebagai Dasar Pemberian Bebas Visa Kunjungan

Dasar pemberian bebas visa kunjungan adalah UndangUndang Nomor 6 Tahun 2011 tentang Keimigrasian Pasal 43 yang terrdiri dari 2 ayat yang selengkapnya berbunyi:

(1) Dalam hal tertentu Orang Asing dapat dibebaskan 
dari kewajiban memiliki

visa.

(2) Orang Asing yang dibebaskan dari kewajiban memiliki Visa sebagaimana dimaksud pada ayat (1) adalah:

a. warga negara dari negara tertentu yang ditetapkan berdasarkan Peraturan Presiden dengan memperhatikan asas timbal balik dan asas manfaat;

b. warga negara asing pemegang izin tinggal yang memiliki izin masuk kembali yang masih berlaku;

c. nakhoda, kapten pilot, atau awak yang sedang bertugas di alat angkut;

d. nakhoda, awak kapal, atau tenaga ahli asing di atas kapal laut atau alat apung yang datang langsung dengan alat angkutnya untuk beroperasi di perairan Nusantara, laut teritorial, landas kontinen, dan/atau zona ekonomi eksklusif Indonesia.

Selanjutnya sesuai dengan amanat pasal 43 ayat (1) di atas, maka pemerintah dalam hal ini Presiden mengeluarkan Peraturan Presiden Nomor 69 Tahun 2015 tentang Bebas Visa Kunjungan yang ditetapkan oleh Presiden Republik Indonesia Joko Widodo di Jakarta pada tanggal 9 Juni 2015 dan diundangkan oleh Menteri Hukum dan Hak Asasi Manusia Republik Indonesia Yasona H. Laoly di Jakarta pada tanggal 10 Juni 2015.

$$
\text { Peraturan }
$$

Presiden Nomor 69 Tahun 2015 tentang Bebas Visa Kunjungan dengan tegas menyatakan bahwa dasar hukum pembentukan Peraturan Presiden ini sebagaimana tertuang dalam bagian dasar hukum yang didahului oleh kata "mengingat" yaitu:
1. Pasal 4 ayat (1) Undang- Undang Dasar Negara Republik Indonesia Tahun 1945;


2. Undang-Undang Nomotr 6 Tahun 2011 tentang

Keimigrasian (Lembaran

Negara Republik Indonesia

Tahun 2011Nomor 52,

Tambahan Lembaran Negara

Republik Indonesia Nomor 5216);

3. Peraturan Pemerintah Nomor 31 Tahun 2013 tentang Peraturan Pelaksanaan Undang-Undang Nomer 6 Tahun 2011 tentang Keimigrasian (Lembaran Negara Republik Indonesia Tahun 2013 Nomor 68, Tambahan Lembaran Negara Republik Indonesia Nomor 5409);

Berdasarkan pernyataan tersebut maka dapat dilihat bahwa Peraturan Presiden Ini bersumber dari peraturan yang mengatur tentang keimigrasian baik itu berupa Undang-Undang maupun Peraturan Pemerintah yang menggerakkan UndangUndang tersebut.

Bagian Konsiderans

Peraturan Presiden Nomor 69 Tahun 2015 tentang Bebas Visa
Kunjungan memuat hal-hal sebagai berikut yang diawali dengan kalimat "menimbang", yaitu:

a. bahwa dalam rangka meningkatkan hubungan Negara Republik Indonesia dengan negara lain, perlu diberikan kemudahan bagi orang asing warga negara dari negara tertentu untuk masuk ke wilayah Negara Republik Indonesia yang dilaksanakan dalam bentuk pembebasan dari kewajiban memiliki visa kunjungan dengan memperhatikan asas timbal balik dan manfaat;

b. bahwa pembebasan dari kewajiban memiliki visa kunjungan bagi orang asing warga negara dari negara tertentu dimaksudkan untuk memberikan manfaat dalam pembangunan nasional pada umumnya dan peningkatan perekonomian khususnya;

c. bahwa pembebasan dari kewajiban memiliki visa kunjungan bagi orang asing warga negara dari negara 
tertentu sebagaimana diatur

dalam Keputusan Presiden

Nomor 18 Tahun 2003

tentang Bebas Visa

Kunjungan Singkat

sebagaimana telah beberapa

kali diubah terakhir dengan

Peraturan Presiden Nomor 43

Tahun 2011 tentang

Perubahan Ketiga atas

Keputusan Presiden Nomor

18 Tahun 2003 perlu

disesuaikan dengan Undang-

Undang Nomor 6 Tahun 2011

tentang Keimigrasian;

d. bahwa berdasarkan

pertimbanngan sebagaimana

dimaksud dalam huruf a,

huruf $\mathrm{b}$ dan huruf $\mathrm{c}$, perlu

menetapkan Peraturan

Presiden tentang Bebas Visa

Kunjungan;

Berdasarkan konsiderans

tersebut ditegaskan bahwa

pembebasan dari kewajiban

memilik visa bagi orang asing warga negara dari negara tertentu harus berasaskan asas timbalbalik (resiprositas) dan asas manfaat. Bahwa penggunaan kata "dan" mengandung arti bahwa satu sama lain harus terpenuhi, bukan pilihan dan bukan pemisahan melainkan menjadi satu kesatuan yang saling menguatkan.

Dalam penjelasan atas Undang-Undang Nomor 6 Tahun 2011 tentang Keimigrasian terdapat paragraf yang membahas tentang pertimbangan untuk memperbarui Undang-Undang Nomor 9 Tahun 1992 tentang Keimigrasian, dimana pada pertimbangan huruf $\mathrm{g}$ menyatakan bahwa hak kedaulatan negara dalam penerapan prinsip timbal balik resiprositas ) mengenai pemberian visa terhadap orang asing. Hal ini mengandung arti bahwa seluruh kebijakan mengenai pemberian visa harus berdasarkan asas timbal balik yang menandakan bahwa negara Indonesia memiliki kedaulatan atas wilayah, penduduk dan lalu lintas perpindahan dari atau ke dalam wilayah Republik Indonesia.

$$
\text { Peraturan tentang }
$$

pemberian bebas visa 
menggunakan asas timbal balik sebagai persyaratan utama bagi pemberian pembebasan dari kewajiban memiliki visa bagi orang asing warga negara dari negara tertentu. Keputusan Presiden Nomor 18 Tahun 2003 tentang Bebas Visa Kunjungan Singkat dengan sangat jelas menyatakan bahwa pemberian Bebas Visa Kujungan Singkat harus berdasarkan asas timbal balik atau resiprokal. Aturan ini terdapat pada pasal 2 ayat (2) yang selengkapnya berbunyi: “ ketentuan sebagaimana dimaksud dalam ayat (1) dapat berlaku juga bagi orang asing warga negara dari negara tertentu yang melakukan kerja sama bilateral atau multilateral berdasarkan asas timbal balik atau resiprokal dengan pemerintah Indonesia.

Pasal 3 dalam Keputusan Presiden ini menetapkan 11 negara yang menjadi subyek Bebas Visa Kunjungan Singkat, yaitu Thailand, Malaysia, Singapura, Brunei Darussalam, Phillipina, Hongkong Special Administration Region
(Hongkong SAR), Macao Special Administration Region (Macao SAR), Chili, Maroko, Turki dan Peru.

Keputusan Presiden tentang Bebas Visa Kunjungan Singkat mengalami perubahanperubahan sebagai berikut :

a. Perubahan pertama

Perubahan pertama ditetapkan melalui Keputusan Presiden Nomor 103 Tahun 2003 tentang Perubahan tas keputusan Presiden Nomor 18 Tahun 2003 tentang Bebas Visa Kunjungan Singkat. Pada perubahan pertama ini terjadi perubahan penetapan negara-negara yang menjadi subyek pemberian Bebas Visa Kunjungan Singkat. Jumlahnya tetap 11 negara dengan menghapus negara Turki dan menggantinya dengan negara Vietnam.

b. Perubahan kedua

Perubahan kedua ditetapkan melalui Peraturan Presiden

Nomor 16 Tahun 2008 tentang Perubahan Kedua Atas Keputusan Presiden 


\begin{tabular}{|c|c|}
\hline Nomor 18 Tahun & Kunjungan \\
\hline Tentang & perubahannya, \\
\hline Kunjungan Singkat. Pada & yang menjadi subyek Bebas Visa \\
\hline perubahan kedua ini jumlah & Kunjungan \\
\hline negara yang menjadi subyek & memberlakukan hal yang sama \\
\hline kunjungan & kepada warga negara Indonesia \\
\hline bertambah satu & yang akan berkunjung ke negara- \\
\hline negara yaitu & tersebut. \\
\hline sehingga & demikian \\
\hline keseluruannya menjadi 12 & (resiprokal/resiprositas) \\
\hline negara. & menjadi dasar pemberlakuan \\
\hline Perubahan ketiga & Keputusan Presiden \\
\hline Perubahan ketiga ditetapkan & telah terpenuhi. \\
\hline melalui Peraturan Presiden & Keberadaan \\
\hline Nomor $43 \quad$ Tahun 2011 & Pemerintah No. 69 Tahun 2015 \\
\hline tentang Perubahan Ketiga & Undang-Undang \\
\hline Atas Keputusan & Nomor 6 Tahun 2011 dan \\
\hline Nomor 18 Tahun & Peraturan Pemerintah Nomor \\
\hline Tentang & Tahun \\
\hline Kunjungan Singkat. Pada & Pelaksanaan \\
\hline perubahan ketiga ini jumlah & Undang-Undang \\
\hline negara yang menjadi subyek & Tahun \\
\hline kunjungan & Keimigrasian \\
\hline Singkat bertambah tiga & Peraturan \\
\hline negara yaitu Kamboja, Laos & Nomor 69 Tahun 2015 tentang \\
\hline dan Myanmar, sehingga & Bebas Visa Kujungan sama \\
\hline jumlah keseluruannya & sekali merupakan peraturan yang \\
\hline menjadi 15 negara. & baru yang bukan merupakan \\
\hline Pada saat berlakunya & perubahan atas \\
\hline eputusan Presiden Nomor 18 & Presiden Nomor 18 Tahun 2003 \\
\hline Iun 2003 Tentang Bebas Visa & tentang Bebas Visa Kunjungan \\
\hline
\end{tabular}


Singkat. Namun isi dari peraturan presiden ini juga mengatur apa yang telah diatur sebelumnya dalam Keputusan Presiden Nomor 18 Tahun 2003 tentang Bebas Visa Kunjungan Singkat beserta peraturan perubahannya ditambah dengan pemeberlakukan bebas visa kunjungan kepada orang asing warga negara dari negara tertentu yang akan berkunjung ke Indonesia dalam rangka wisata. Dengan berlakunya Peraturan Presiden Nomor 69 Tahun 2015 Tentang Bebas Visa Kunjungan maka secara garis besar pemberian pembebasan dari kewajiban memiliki visa bagi orang asing warga negara dari negara tertentu dibagi menjadi dua bagian, yaitu orang asing yang berkunjung dalam rangka wisata dan orang asing warga negara dari negara tertentu yang menjadi subyek bebas visa kunjungan singkat berdasarkan Keputusan Presiden Nomor 18 Tahun 2003 tentang Bebas Visa Kunjungan Singkat sebagaimana telah beberapa kali diubah terakhir dengan Peraturan Presiden Nomor 43 tahun 2011 tentang perubahan ketiga atas Keputusan Presiden Nomor 18 tahun 2003 tenatng Bebas Visa Kunjungan Singkat.

Meskipun Peraturan Presiden ini bukan merupakan perubahan atas keputusan presiden tentang bebas visa kunjungan singkat, namun dasar pemberian bebas visa kunjungan berdasarkan Peraturan Presiden ini sama dengan dasar pemberian bebas visa kunjungan singkat berdasarkan keputusan presiden sebelumnya yaitu berdasarkan asas timbal balik dan asas manfaat. Hal ini diatur pada Peraturan Presiden Nomor 69 Tahun 2015 tentang Bebas Visa Kunjungan pasal 2 yang berbunyi "bebas visa kunjungan diberikan kepada orang asing warga negara dari negara tertentu dan pemerintah wilayah administratif khusus dari negara tertentu dengan memperhatikan asas timbal balik dan asas manfaat." Dengan kata lain pemberian bebas visa kunjungan harus 
memenuhi kedua asas tersebut dan tidak boleh hanya salah satu asas saja yang terpenuhi.

Peraturan Presiden tentang bebas visa kunjungan ini menetapkan 45 negara yang menjadi subyek bebas visa kunjungan yang terdiri dari 30 negara sebagai subyek bebas visa kunjungan untuk wisata dan 15 negara terdahulu yang menjadi subyek bebas visa kunjungan singkat. Untuk 15 negara subyek Bebas Visa Kunjungan Singkat asas timbal balik dan asas manfaat sudah terpenuhi, dimana warga negara Indonesia pun mendapat fasilitas bebas visa jika ingin berkunjung ke 15 negara tersebut. Namun lain halnya dengan 30 negara yang menjadi subyek yang menjadi subyek bebas visa kunjungan wisata, asas manfaat memang terpenuhi namun asas timbal balik (resiprositas) tidak terpenuhi. Tidak semua dari 30 negara tersebut memberikan fasilitas yang sama kepada warga negara Indonesia yang akan berkunjung atau berwisata ke negaranya.
Sampai dengan saat ini hanya satu negara dari 30 negara subyek bebas visa kunjungan wisata yang memberikan fasilitas yang sama kepada warga negara Indonesia yaitu Jepang, itupun dengan mekanisme yang tidak mudah. Pemerintah Jepang memberikan bebas visa kunjungan wisata kepada warga negara Indonesia yang sudah memiliki Paspor Elektronik (epassport) dan harus mendaftar di Kedutaan Besar Negara Jepang di Jakarta yang selanjutnya akan diinput dalam database keimigasian negara Jepang yang memuat informasi orang asing dalam hal ini adala warga negara Indonesia yang akan berkunjungan ke Jepang dan ditempelkan sticker bebas visa kunjungan pada paspor warga negara Indonesia tersebut dan diterakan cap/stamp pada sticker tersebut. Jadi, tidak serta merta seluruh warga negara Indonesia bebas masuk ke Jepang melainkan ada tahapan-tahapan yang harus dilalui untuk mendapatkan bebas visa 
kunjungan wisata ke Jepang. Ini berbeda sekali dengan perlakuan pemerintah Indonesia kepada seluruh negara subyek Bebas Visa Kunjungan bahwa seluruh warga negaranya serta merta dapat langsung datang ke Indonesia sepanjang memenuhi syarat administrasi yaitu paspor yang masih berlaku dan tidak termasuk daftar Cekal tanpa harus melapor ke kedutaan negara Indonesia di negaranya. Sekali lagi langkah ini ditempuh dengan alasan untuk meningkatkan jumlah wisatawan mancanegara sehingga devisa negara dari sektor pariwisata akan meningkat secara signifikan. Hal ini sesuai dengan target Kementerian Pariwisata yang menargetkan jumlah kunjungan wisatawan mancanegara akan meningkat menjadi 10 juta pengunjungan dengan diberlakukannya bebas visa kunjungan untuk wisata ini.

Kedudukan

Peraturan

Presiden dalam hierarki perarturan perundang-undangan Republik Indonesia berada di bawah Peraturan Pemerintah dan Undang-Undang atau Peraturan Pemerintah Pengganti UndangUndang. Hal ini diatur dalam Pasal 7 ayat (1) dan (2) UndangUndang Nomor 12 Tahun 2011 tentang Pembentukan Peraturan Perundang-undangan yang selengkapnya berbunyi:

(1) Jenis dan hierarki Peraturan Perundang-undangan terdiri atas:

a. Undang-Undang Dasar Negara Republik Indonesia Tahun 1945;

b. Ketetapan Majelis Permusyawaratan Rakyat;

c. Undang-Undang/Peraturan Pemerintah Pengganti Undang-Undang;

d. Peraturan Pemerintah;

e. Peraturan Presiden;

f. Peraturan Daerah Provinsi; dan

g. Peraturan Daerah Kabupaten/Kota.

(2) Kekuatan hukum Peraturan Perundang-undangan sesuai dengan hierarki sebagaimana dimaksud pada ayat (1). 
Berdasarkan hierarki

tersebut maka urutan berdasarkan kekuatan hukum yang mengikat dari yang paling lemah kepada yang paling kuat dalam konteks pemberian bebas visa kunjungan adalah Peraturan Presiden Nomor 69 Tahun 2015 tentang Bebas Visa Kunjungan kemudian Peraturan Pemerintah Nomor 31 Tahun 2013 tentang Peraturan Pelaksanaan Undang-Undang Nomor 6 Tahun 2011 tentang Keimigrasian dan yang paling kuat adalah Undang-Undang Nomor 6 Tahun 2011 tentang Keimigrasian. Dengan demikian maka Peraturan Presiden tidak boleh bertentangan dengan Peraturan Pemerintah dan lebih tinggi lagi bahwa Peraturan Presiden tidak boleh bertentangan dengan UndangUndang dalam hal ini adalah tentang keimigrasian. Hal ini sesuai dengan apa yang diamanatkan oleh UndangUndang Nomor 12 Tahun 2011 tentang Pembentukan Peraturan Perundang-undangan Pasal 13 yang menyatakan bahwa materi muatan Peraturan Presiden berisi materi yang diperintahkan oleh Undang-Undang, materi untuk melaksanakan Peraturan Pemerintah, atau materi untuk melaksanakan penyelenggaraan kekuasaan pemerintahan.

Undang-Undang Nomor 6 Tahun 2011 tentang keimigrasian pada bagian penjelasan yang merupakan bagian yang tidak terpisahkan dari keseluruhan Undang-Undang tersebut mengatur pemberian pembebasan dari kewajiban memiliki visa bagi orang asing warga negara dari negara tertentu dalam pasal 42 ayat (1) dan (2). Secara spesifik dijelaskan melalui penjelasan pasal 43 ayat (2) huruf a bahwa yang dimaksud dengan "pembebasan visa" dalam ketentuan ini misalnya untuk kepentingan pariwisata yang membawa manfaat bagi perkembangan pembangunan nasional dengan memperhatikan asas timbal balik, yaitu pembebasan visa hanya diberikan kepada orang asing dari negara yang juga memberikan 
pembebasan visa kepada warga

negara Indonesia.

Dengan demikian maka

Peraturan Presiden Nomor 69

Tahun 2015 tentang Bebas Visa

Kunjungan bertentangan dengan

Undang-Undang Nomor 6 Tahun

2011 dan Peraturan Pemerintah

Nomor 31 Tahun 2013 tentang

Peraturan Pelaksanaan Undang-

Undang Nomor 6 Tahun 2011

tentang Keimigrasian sehingga

Peraturan Presiden ini dapat

dibatalkan sepanjang ada pihak

yang mau mengajukan

pengujiannya ke Mahkamah

Agung. Hal ini diatur dalam

Undang-Undang Nomor 12

Tahun $2011 \quad$ tentang

Pembentukan Peraturan

Perundang-undangan Pasal 9 ayat

(2) yang berbunyi: "Dalam hal suatu Peraturan Perundangundangan di bawah UndangUndang diduga bertentangan dengan Undang-Undang, pengujiannya dilakukan olehh Mahkamah Agung.

\section{Kesimpulan}

Ditinjau dari aspek yuridis, maka Peraturan Presiden
Nomor 69 Tahun 2015 tentang Bebas Visa Kunjungan bertentangan dengan aturan perundang-undangan di atasnya yaitu Undang-Undang Nomor 6 Tahun 2011 tentang Keimigrasian. Hal yang tidak sesuai adalah pada bagian asas pemberian atau pemberlakuan bebas visa kunjungan yang berasaskan asas timbal balik (resiprositas) dan asas manfaat. Undang-Undang Nomor 6 Tahun 2011 tentang Keimigrasian mengatur pemberian bebas visa di pasal 43 ayat 1 dan 2 dengan dasar pemberian ada pada pasal 43 ayat (2) huruf a yaitu harus memperhatikan asas timbal balik dan asas manfaat. Hal ini ditegaskan pada bagian penjelasan Undang-Undang tersebut yang secara spesifik menjelaskan bahwa pemberian bebas visa untuk pariwisata harus berlaku asas timbal balik (resiprositas). Sementara Peraturan Presiden Nomor 69 Tahun 2015 tentang Bebas Visa Kunjungan Pasal 3 denga jelas meyatakan bahwa tujuan 
pemberian bebas visa untuk negara tertentu -dalam hal ini 30 negara yang baru menjadi subyek bebas visa kunjungan- adalah dalam rangka kunjungan wisata. Dengan demikian maka baik asas resiprositas maupun asas manfaat yang menjadi dasar pertimbangan pemberian bebas visa kunjungan belum terpenuhi dalam Peraturan Presiden Nomor 69 Tahun 2015 tentang Bebas Visa Kunjungan.

\section{DAFTAR BACAAN}

\section{Buku}

Amin Suprihatini, 2008, Hubungan Internasional, Cempaka Putih, Klaten.

Bagir Manan, 2000, Arogansi MPR, dalam Harian Republik, Rabu, 9 April 2000

$\begin{array}{lr}\text { Keimigrasian } & \text { Hukum } \\ \text { Sistem Hukum Nasional, } \\ \text { Ghalia Indonesia, Jakarta. }\end{array}$

Boer Mauna, 2001, Hukum Internasional-Pengertian Peranan Dan Fungsi Dalam Era Dinamika Global, Alumni, Bandung.

Hans Kelsen, 1986, General Theory of Law and State,
Translate by Anders Wedberg, Russel \& Russel, New York.

$\begin{array}{llr}\text { Murni, } & \text { cet. } & \text { VIII, } \\ \text { terjemahan } & \text { Raisul } \\ \text { Muttaqien, Nusa } & \text { Media, } \\ \text { Bandung. } & & \end{array}$

J.G. Starke, 1989, Pengantar Hukum Internasional, Edisi Kesepuluh. Sinar Grafika, Jakarta.

Mochtar Kusumaatmadja, Fungsi dan Perkembangan Hukum Dalam Pembangunan Nasional, Binacipta. Bandung.

Mochtar Kusumaatmadja dan Etty R. Agoes, 2010, Pengantar Hukum Internasional, Alumni, Bandung.

Sudikno Mertokusumo dan A. Pitlo, 1993, Bab-Bab Tentang Penemuan Hukum, Citra Aditya Bakti, Bandung.

Soeprapto, Maria Farida Indrati, 1998, Ilmu PerundangUndangan Dasar dan Pembentukannya, Kanisius, Yogyakarta. 